LINGUA, Vol. 14, No. 1, Maret 2017

p ISSN: 1979 9411; e ISSN: 2442 238X

Http://lingua.pusatbahasa.or.id; Email: presslingua@gmail.com

Center of Language and Culture Studies, Surakarta, Indonesia

Suwarno. 2017. Budaya Huma Betang Masyarakat Dayak Kalimantan Tengah

dalam Globalisasi: Telaah Konstruksi Sosial. Lingua (2017), 14(1): 89 102.

\title{
BUDAYA HUMA BETANG MASYARAKAT DAYAK KALIMANTAN TENGAH DALAM GLOBALISASI: TELAAH KONSTRUKSI SOSIAL
}

\author{
Suwarno \\ Pascasarjana FISIP Universitas Kadiri \\ Jl. Selomangleng No. 1 Kota Kediri 64115 \\ Email: 4kangone@gmail.com
}

Diterima tanggal: 10 November 2016

Diterima untuk diterbitkan tanggal: 10 Desember 2016

\begin{abstract}
This paper is an antropological review on Dayak tradition of Huma Betang, a traditional house for Dayak community in Central Kalimantan. Huma betang or betang has a length of 30-150 meters, 10-30 meters wide and 3-5 meter high. The building uses high quality iron wood, can stand up to hundreds of years as well as anti-termite. It used to be inhabited by 100-150 people, inhabited by one big family and headed by a Pambakas Lewu. Studies on people's living in Betang Damang Tumbang Anoi Gunung Mas found several cultural values of Betang Dayak community: (1) hapsari, (2) handep, (3) belom bahadat, and (4) hapakat kula. Hapahari is defined as a brotherhood and togetherness in life betang. Handep is mutual help, pandohop (aid), mutual mandohop (help). Belom bahadat (live civilized and ethical) is a rule or etiquette that govern life together, that appreciate the prevailing custom in the territories of indigenous communities concerned. Hapakat kula (mutually agree) is a hallmark of life of the inhabitants betang. Occupants of betang held deliberations in any activities of common interest of tradition betang inhabitants since centuries ago.
\end{abstract}

Keywords: huma betang, dayak, tradition, occupant.

Dalam kajian budaya, setiap orang memiliki kemampuan untuk berekspresi walaupun dalam skala mikro (micro forces of expression) yang diwujudkan melalui unsur-unsur pembentuk persepsi dan sistem makna, seperti kebiasaan berpikir, ungkapan perasaan (emosi), perilaku serta sistem pembentuk nilai yang merupakan refleksi dari akal budinya. Oleh karena itu individu adalah pintu masuk untuk menyingkapkan makna-makna yang tersebar dalm banyak kebenaran di level kehidupan sosial (Muji Sutrisno dan Hendar Putrsnto, 2005:74-75).

Membuat kajian tentang masyarakat Dayak, menurut berbagai tulisan antropolog, harus dicari dalam pola-pola tempat tinggal mereka yang khas. Pada 
LINGUA, Vol. 14, No. 1, Maret 2017

p ISSN: 1979 9411; e ISSN: 2442 238X

Http://lingua.pusatbahasa.or.id; Email: presslingua@gmail.com

Center of Language and Culture Studies, Surakarta, Indonesia

Suwarno. 2017. Budaya Huma Betang Masyarakat Dayak Kalimantan Tengah

dalam Globalisasi: Telaah Konstruksi Sosial. Lingua (2017), 14(1): 89 102.

umumnya etnografi tentang Dayak secara khusus memfokuskan diri pada rumah panjang, bukan hanya sebagai bentuk arsitekturnya melainkan lebih sebagai sesuatu yang merupakan perwujudan dari sebuah struktur hubungan-hubungan sosial khas Dayak (Yekti Maunati, 2004:62). Kehidupan di rumah panjang (Betang) secara efektif menampilkan fungsi yang sama dengan fungsi sebuah desa (Lebar, 1972:169 dalam Maunati, 2004:63).

Sementara itu Widjono (1998:7) mengetengahkan pandangan masyarakat Dayak mengenai huma betang ${ }^{l}$ yang tercermin dalam beberapa aspek berikut ini: Pertama, aspek penghunian. Rumah betang merupakan struktur multi-keluarga permanen dan terutama berfungsi sebagai tempat tinggal utama di samping rumah pondok di ladang. Kedua, aspek hukum dan hak milik. Rumah betang mempunyai aspek kepemilikan yang jelas. Terutama adalah hak kepemilikan semua keluarga secara bersama menguasai semua tanah diwilayah betang. Hak wilayah rumah betang merupakan hak sekunder, sedangkan hak primer dipegang oleh tiap-tiap keluarga atau kelompok keluarga kecil yang memiliki ikatan kekerabatan. Rumah betang juga merupakan unit peradilan yang sangat penting. Acap kali pertikaian antar anggota rumah betang dapat diselesaikan oleh tetua adat secara internal. Satu hal yang menonjol adalah wewenang seseorang atau satu keluarga tertentu relatif kecil, yang jauh lebih penting adalah wewenang rumah betang secara keseluruhan. Hal itu disebabkan adanya egalitarisme yang kuat dalam masyarakat Dayak. Ketiga, aspek ekonomi. Rumah betang memegang peranan penting dalam distribusi arus tenaga kerja dan hasil kerja antarkeluarga. Pemakaian tenaga kerja tambahan dari keluarga lain, merupakan kunci dari sistem perladangan yang mereka jalankan.

Florus, dkk. (1994:246) mengisyaratkan bahwa rumah betang memang bukan sebuah hunian mewah dengan aneka perabotan canggih seperti yang diidamkan oleh masyarakat modern saat ini. Rumah betang cukuplah dilukiskan sebagai sebuah hunian yang sederhana dengan perabotan seadanya. Namun, dibalik kesederhanaan itu, rumah betang menyimpan sekian banyak makna dan sarat akan nilai-nilai kehidupan yang unggul. Tak dapat dipungkiri bahwa rumah betang telah menjadi simbol yang kokoh dari kehidupan komunal masyarakat Dayak. Dengan mendiami rumah betang dan

\footnotetext{
${ }^{1}$ Huma Betang atau rumah betang memiliki panjang 30-150 meter, lebar 10-30 meter, dan tinggi tiang 3-5 meter. Bangunan menggunakan kayu ulin berkualitas tinggi, bisa berdiri sampai ratusan tahun serta anti rayap. Dulu dihuni oleh 100-150 jiwa. Betang ialah rumah suku karena dihuni satu keluarga besar dan dipimpin oleh seorang Pambakas Lewu. Huma Betang dibagi beberapa ruangan yang dihuni oleh setiap keluarga. Di halaman depan terdapat balai untk menerima tamu atau pertemuan adat dan juga sapundu. Sapundu ialah patung atau totem, umumnya berbentuk manusia yang memiliki ukiran khas. Sapundu berfungsi sebagai tempat untuk mengikatkan binatang-binatang yang akan dikorbankan untuk prosesi upacara adat. Terkadang terdapat juga patahu yang berfungsi sebagai rumah pemujaan. Pada bagian belakang terdapat balai berukuran kecil atau tukau yaitu gudang untuk menyimpan alat-alat pertanian, seperti lisung atau halu. Pada bagian depan atau bagian belakang biasanya terdapat pula sandung. Sandung adalah tempat penyimpanan tulang-tulang keluarga yang sudah meninggal serta telah melewati proses upacara tiwah.
} 
LINGUA, Vol. 14, No. 1, Maret 2017

p ISSN: 1979 9411; e ISSN: 2442 238X

Http://lingua.pusatbahasa.or.id; Email: presslingua@gmail.com

Center of Language and Culture Studies, Surakarta, Indonesia

Suwarno. 2017. Budaya Huma Betang Masyarakat Dayak Kalimantan Tengah

dalam Globalisasi: Telaah Konstruksi Sosial. Lingua (2017), 14(1): 89 102.

menjalani segala proses kehidupan di tempat tersebut, masyarakat Dayak menunjukkan bahwa mereka juga memiliki naluri untuk selalu hidup bersama dan berdampingan dengan warga masyarakat lainnya. Mereka mencintai kedamaian dalam komunitas yang harmonis sehingga mereka berusaha keras untuk mempertahankan tradisi rumah betang ini. Harapan ini didukung oleh kesadaran setiap individu untuk menyelaraskan setiap kepentingannya dengan kepentingan bersama. Kesadaran tersebut dilandasi oleh alam pikiran religio-magis, yang menganggap bahwa setiap warga mempunyai nilai dan kedudukan serta hak hidup yang sama dalam lingkungan masyarakatnya.

Pada peradaban sekarang ini, karena pengaruh globalisasi, huma betang sudah ditinggalkan, hanyabeberapa keluarga saja yang masih bermukim di sana. Namun tradisi dan budaya yang diabstraksikan dari interaksi dalam huma betang tersebut masih dipertahankan dalam alam pemikiran masyarakat Dayak.Pertanyaan penting yang patut diajukan adalah apakah tradisi dan budaya huma betang itu masih mampu menjawab tantangan globalisasi saat ini? Ataukah memang budaya huma betang ini sengaja dibuat resisten dengan mengatasnamakan integrasi? Atau lebih jauh lagi apakah resistensi budaya betang diciptakan karena muatan politis tertentu berkaitan dengan konteks Kalimantan Tengah yang masih membangun dan eksploitasi sumberdaya dalam segala aspek.

Beberapa pertanyaan tadi penting untuk dirangkum menjadi tujuan kecil dari telaah ini, yaitu mengkaji konstruksi sosial budaya huma betang dalam kaitannya dengan tantangan globalisasi saat ini. Upaya tersebut tentunya dengan mencari dan mendalami berbagai pandangan mengenai budaya huma betang yang dikonstruksikan oleh masyarakat Dayak sendiri, dikenal sebagai pandangan tahan lama, tidak bisa diruntuhkan, mengakar. Pandangan-pandangan itu nantinya akan dihadapmukakan dengan persoalan-persoalan globalisasi yang mengemuka saat ini.

\section{KERANGKA KONSTRUKSI SOSIAL}

Berger dan Luckman (1990:70) mengatakan institusi masyarakat tercipta dan dipertahankan atau diubah melalui tindakan dan interaksi manusia. Meskipun masyarakat dan institusi sosial terlihat nyata secara obyektif, namun pada kenyataan semuanya dibangun dalam definisi subjektif melalui proses interaksi. Objektivitas baru bisa terjadi melalui penegasan berulang-ulang yang diberikan oleh orang lain yang memiliki definisi subyektif yang sama. Pada tingkat generalitas yang paling tinggi, manusia menciptakan dunia dalam makna simbolis yang universal, yaitu pandangan hidupnya yang menyeluruh, yang memberi legitimasi dan mengatur bentuk-bentuk sosial serta memberi makna pada berbagai bidang kehidupannya.

Pola konstruksisosial berlangsung melalui interaksi sosial yang dialektis dari tiga bentuk realitas yang menjadi konsep utama, yakni subjective reality, symbolic reality dan objective reality. (1) Objective reality, merupakan suatu kompleksitas definisi realitas (termasuk ideologi dan keyakinan) serta rutinitas tindakan dan tingkah laku yang telah mapan terpola, yang kesemuanya dihayati oleh individu secara umum sebagai fakta; (2) Symbolic reality, merupakan semua ekspresi simbolik dari apa yang 
LINGUA, Vol. 14, No. 1, Maret 2017

p ISSN: 1979 9411; e ISSN: 2442 238X

Http://lingua.pusatbahasa.or.id; Email: presslingua@gmail.com

Center of Language and Culture Studies, Surakarta, Indonesia

Suwarno. 2017. Budaya Huma Betang Masyarakat Dayak Kalimantan Tengah

dalam Globalisasi: Telaah Konstruksi Sosial. Lingua (2017), 14(1): 89 102.

dihayati sebagai "objective reality" misalnya teks produk industri media, seperti berita di media cetak atau elektronika, begitu pun yang ada di film-film; (3) Subjective reality, merupakan konstruksi definisi realitas yang dimiliki individu dan dikonstruksi melalui proses internalisasi. Realitas subjektif yang dimiliki masing-masing individu merupakan basis untuk melibatkan diri dalam proses eksternalisasi, atau proses interaksi sosial dengan individu lain dalam sebuah struktur sosial. Melalui proses eksternalisasi itulah individu secara kolektif berpotensi melakukan objectivikasi, memunculkan sebuah konstruksi objektive reality yang baru (Berger \& Luckman, 1990:76).

Berger menemukan konsep untuk menghubungkan antara yang subjektif dan objektif melalui konsep dialektika. Proses dialektik fundamental dari masyarakat terdiri dari tiga momentum, yaitu eksternalisasi, objektivasi, dan internalisasi. Pemahaman secara seksama terhadap tiga momentum ini akan diperoleh suatu pandangan atas masyarakat yang memadai secara empiris.

Eksternalisasi adalah suatu pencurahan kedirian manusia secara terusmeneruske dalam dunia, baik dalam aktivitas fisis maupun mentalnya.Penyesuaian diri dengan dunia sosio-kultural sebagai produk manusia ("Society is a human product"). Produk aktivitas manusia-yang berupa produk-produk sosial terlahir dari eksternalisasi manusia. Eksternalisasi merupakan keharusan antropologis; keberadaan manusia tidak mungkin berlangsung dalam suatu lingkungan interioritas yang tertutup dan tanpagerak. Keharusan antropologis itu berakar dalam kelengkapan biologis manusia yang tidak stabil untuk berhadapan dengan lingkungannya.

Kedirian manusia adalah melakukan eksternalisasi yang terjadi sejak awal, karena ia dilahirkan belum selesai, berbeda dengan binatang yang dilahirkan dengan organisme yang lengkap. Untuk menjadi manusia, ia harus mengalami perkembangan kepribadian dan perolehan budaya. Keadaan manusia yang belum selesai pada saat dilahirkan, membuat dirinya tidak terspesialisasi dari struktur instingtualnya, atau dunianya tidak terprogram. Dunia manusia adalah dunia yang dibentuk (dikonstruksi) oleh aktivitas manusia sendiri; ia harus membentuk dunianya sendiri dalam hubungannya dengan dunia. Dunia manusia yang dibentuk itu adalah kebudayaan, yang tujuannya memberikan struktur-struktur yang kokoh yang sebelumnya tidak dimilikinya secara biologis. Oleh karena merupakan bentukan manusia, struktur-struktur itu bersifat tidak stabil dan selalu memiliki kemungkinan berubah.Itulah sebabnya, kebudayaan selalu dihasilkan dan dihasilkan kembali oleh manusia.Ia terdiri atas totalitas produkproduk manusia, baik yang berupa material dan nonmaterial. Manusia menghasilkan berbagai jenis alat, dan dengan alat-alat itu pula manusia mengubah lingkungan fisis dan alam sesuai dengan kehendaknya. Manusia menciptakan bahasa dan membangun simbol-simbol yang meresapi semua aspek kehidupannya.

Objektivasi adalah disandangnya produk-produk aktivitas itu (baik fisik maupun mental), suatu realitas yang berhadapan dengan produsennya semula, dalam bentuk suatu kefaktaan (faktisitas) yang eksternal terhadap, dan lain dari produsen itu sendiri. Objektivasi juga merupakan interaksi sosial dalam dunia intersubjektif yang dilembagakan atau mengalami institusionalisasi. "Society is an objective reality". Bagi 
LINGUA, Vol. 14, No. 1, Maret 2017

p ISSN: 1979 9411; e ISSN: 2442 238X

Http://lingua.pusatbahasa.or.id; Email: presslingua@gmail.com

Center of Language and Culture Studies, Surakarta, Indonesia

Suwarno. 2017. Budaya Huma Betang Masyarakat Dayak Kalimantan Tengah

dalam Globalisasi: Telaah Konstruksi Sosial. Lingua (2017), 14(1): 89 102.

Berger, masyarakat adalah produk manusia, berakar pada fenomena eksternalisasi. Produk manusia (termasuk dunianya sendiri), kemudian berada di luar dirinya, menghadapkan produk-produk sebagai faktisitas yang ada di luar dirinya.Meskipun semua produk kebudayaan berasal dari (berakar dalam) kesadaran manusia, namun produk bukan serta-merta dapat diserap kembali begitu saja ke dalam kesadaran. Kebudayaan berada di luar subjektivitas manusia, menjadi dunianya sendiri. Dunia yang diproduksi manusia memperoleh sifat realitas objektif. Semua aktivitas manusia yang terjadi dalam eksternalisasi, dapat mengalami proses pembiasaan (habitualisasi) yang kemudian mengalami institusionalisasi (Berger \& Luckman, 1990:75-76).

Kelembagaan berasal dari proses pembiasaan atas aktivitas manusia. Setiap tindakan yang sering diulangi, akan menjadi pola. Pembiasaan, yang berupa pola, dapat dilakukan kembali di masa mendatang dengan cara yang sama, dan juga dapat dilakukan di mana saja. Dalam kerangka pembiasaan ini, juga sangat mungkin terjadi inovasi. Namun, proses-proses pembiasaan mendahului sikap pelembagaan. Pelembagaan, bagi Berger dan Luckmann terjadi apabila ada tipifikasi yang timbalbalik dari tindakan-tindakan yang terbiasakan bagi berbagai tipe pelaku. Tiap tipifikasi semacam itu merupakan suatu lembaga. Tipifikasi tindakan-tindakan yang sudah dijadikan kebiasaan, yang membentuk lembaga-lembaga, merupakan milik bersama. Tipifikasi-tipifikasi itu tersedia bagi semua anggota kelompok sosial tertentu, dan lembaga-lembaga itu mentipifikasi pelaku-pelaku individual ataupun tindakantindakannya.Tipifikasi-tipifikasi timbal-balik itu terjadi secara diakronik dan bukan seketika. Lembaga-lembaga juga mengendalikan perilaku manusia dengan menciptakan pola-pola perilaku.Pola-pola inilah yang kemudian mengontrol yang melekat pada pelembagaan.Segmen kegiatan manusia yang telah dilembagakan berarti telah ditempatkan di bawah kendali sosial. Misalnya, dalam masyarakat Bali, lembaga hukum adat dapat memberikan sanksi kepada anggota masyarakat yang melanggar adat.

Internalisasi merupakan peresapan kembali realitas tersebut oleh manusia, dan mentransformasikannya sekali lagi dari struktur-struktur dunia objektif ke dalam struktur-struktur kesadaran subjektif. Individu mengidentifikasi diri di tengah lembagalembaga sosial atau organisasi sosial di mana individu tersebut menjadi anggotanya. "Man is a social product". Masyarakat dipahami juga sebagai kenyataan subjektif, yang dilakukan melalui internalisasi. Internalisasi adalah suatu pemahaman atau penafsiran individu secara langsung atas peristiwa objektif sebagai pengungkapan makna. Berger dan Luckmann menyatakan, dalam internalisasi, individu mengidentifikasikan diri dengan berbagai lembaga sosial atau organisasi sosial dimana individu menjadi anggotanya.

Subjektivitas itu tersedia secara objektif bagi orang yang menginternalisasi dan bermakna, tidak peduli apakah ada kesesuaian antara kedua makna subjektifnya. Dalam konteks ini, internalisasi dipahami dalam arti umum, yakni merupakan dasar: pertama, bagi pemahaman mengenai sesama, dan kedua, bagi pemahaman mengenai dunia sebagai sesuatu yang maknawi dari kenyataan sosial. Selanjutnya dikatakan Berger dan Luckmann, baru setelah mencapai taraf internalisasi inilah individu menjadi anggota 
LINGUA, Vol. 14, No. 1, Maret 2017

p ISSN: 1979 9411; e ISSN: 2442 238X

Http://lingua.pusatbahasa.or.id; Email: presslingua@gmail.com

Center of Language and Culture Studies, Surakarta, Indonesia

Suwarno. 2017. Budaya Huma Betang Masyarakat Dayak Kalimantan Tengah

dalam Globalisasi: Telaah Konstruksi Sosial. Lingua (2017), 14(1): 89 102.

masyarakat. Proses untuk mencapai taraf itu dilakukan dengan sosialisasi. Ada dua macam sosialisasi, yakni: pertama, sosialisasi primer, adalah sosialisasi pertama yang dialami individu dalam masa kanak-kanak. Kedua, sosialisasi sekunder, adalah setiap proses berikutnya ke dalam sektor-sektor baru dunia objektif masyarakatnya.

\section{BEBERAPA HASIL PENELITIAN TENTANG BUDAYA HUMA BETANG}

Pandangan Laksono, dkk (2006:75) tentang budaya betang yakni merupakan metafor mengenai kebersamaan dalam hidup sehari-hari orang Dayak yang dulu tinggal di rumah betang. Dalam tradisi kehidupan orang Dayak masa lalu, rumah betang bukanlah sekedar tempat bernaung dan berkumpul seluruh anggota keluarga atau melepas keletihan setelah seharian bekerja di ladang. Lebih dari itu, rumah betang adalah jantung dari struktur sosial dalam kehidupan orang Dayak. Setiap kehidupan individu dalam rumah tangga dan masyarakat secara sistematis diatur melalui kesepakatan bersama yang dituangkan dalam hukum adat. Keamanan bersama, baik dari gangguan kriminal atau berbagi makanan, suka-duka maupun mobilisasi tenaga untuk mengerjakan ladang dijamin keberlangsungannya. Nilai yang menonjol dalam kehidupan di rumah betang adalah nilai kebersamaan (komunalisme) di antara para warga yang menghuninya, terlepas dari perbedaan-perbedaan yang mereka miliki.

Studi penelitian yang dilakukan oleh Sukin (2012) bertujuan untuk mendeskripsikan tentang Fungsi Bangunan Rumah Panjang (betang) Bagi Masyarakat Desa Saham Kecamatan Sengah Temila Kabupaten Landak Propinsi Kalimantan Barat. Dengan menggunakan teknik pengumpulan data melalui studi kepustakaan dan teknik observasi langsung ke desa Saham yang masih terdapat bangunan rumah panjang (betang) serta teknik wawancara kepada sejumlah informan. Dengan menggunakan metode deskriptif analitik, maka hasil penelitiannya menemukan bahwa rumah panjang mempunyai peran penting dalam mengembangkan solidaritas sosial suku Dayak Kanayatn. Rumah panjang (betang) juga berfungsi untuk mengembangkan kepribadian seseorang melalui proses sosialisasi. Bagi setiap individu,kehidupan dalam rumah panjang merupakan model kehidupan masyarakat Dayak Kayanatn, serta sistem sosial dalam rumah panjang dapat dipertahankan sejauh mana setiap individu menghayati dan memenuhi perannya yang diharapkan dari padanya.Rumah panjang sebagai wadah sosial merupakan center for Dayak Creation, arts, and inspiration yang membentuk suku Dayak Kanayatn sekaligus menjunjung tinggi nilai kebudayaan.

Kemudian studi yang dilakukan oleh Nugrahaningsih (2013) berkaitan dengan Proses Komunikasi Masyarakat Dayak Ngaju Dalam Rangka Melestarikan Nilai-Nilai Hidup Huma Betang, Studi di lingkungan masyarakat Dayak Ngaju di Desa Buntoi. Penelitian ini mengambil setting pada rumah betang Buntoi yang terletak di kabupaten Pulang Pisau, Kecamatan Kahayan Hilir, Desa Buntoi. Penelitian ini dilakukan untuk mengetahui bagaimana proses komunikasi untuk melestarikan nilai-nilai yang terkandung di dalam Rumah Betang yang terjadi di masyarakat Dayak Ngaju. Hasil penelitian menunjukan bahwa nilai-nilai kehidupan yang berkembang di Rumah Betang mencangkup: nilai untuk hidup saling tolong menolong, rukun, saling menjaga 
LINGUA, Vol. 14, No. 1, Maret 2017

p ISSN: 1979 9411; e ISSN: 2442 238X

Http://lingua.pusatbahasa.or.id; Email: presslingua@gmail.com

Center of Language and Culture Studies, Surakarta, Indonesia

Suwarno. 2017. Budaya Huma Betang Masyarakat Dayak Kalimantan Tengah

dalam Globalisasi: Telaah Konstruksi Sosial. Lingua (2017), 14(1): 89 102.

keamanan dan pertahan serta saling menghargai dan memberi kebebasan beragama. Proses komunikasi masyarakat Dayak Ngaju untuk melestarikan nilai-nilai tersebut adalah dengan melalui proses enkulturasi dan sosialisasi yang dimana pesan-pesan tersebut disampaikan melalui simbol bahasa verbal dan non verbal dengan cara interaksi simbolik. Cara yang paling efektif untuk melakukan transmisi budaya pada masyarakat Dayak Ngaju di desa Buntoi adalah dengan melakukan pewarisan secara verbal diikuti dengan penekanan gerakan non verbal secara berulang.

Studi Penelitian yang dilakukan oleh penulis pada kehidupan masyarakat betang Damang Batu Desa Tumbang Anoi Kabupaten Gunung Mas, menemukan beberapa konstruksi nilai budaya huma betang masyarakat Dayak:

\section{Hapahari}

Hapahari dijelaskan oleh salah satu penghuni betang Damang Batu sebagai persaudaraan dan kebersamaan dalam kehidupan di betang. Penghuni betang mengganggap sesama warga betang adalah saudara yang harus dilindungi, dibantu bila ada kesulitan-kesulitan. Adanya istilah "sama keme, sama mangat, sama susah" merupakan sebuah prinsip bahwa hidup sebagai sesama warga betang sama-sama menanggung, baik suka maupun duka.

Menurut penghuni betang Damang Batu bahwa rasa kebersamaan dan persaudaraan (hapahari) tampak setiap ada permasalahan yang menimpa salah satu penghuni. Jika salah satu anggota keluarga ada yang meninggal dunia maka masa berkabung mutlak diberlakukan selama satu minggu bagi semua penghuni dengan tidak menggunakan perhiasan, tidak berisik, tidak minum tuak dan dilarang menghidupkan peralatan elektronik.

Konsep hapahari inimenurut salah satu tokoh masyarakat Desa Tumbang Anoi juga berdampak bagi perlakuan mereka terhadap orang lain yang bukan komunitas betang. Dalam contoh sederhana mereka menghargai orang luar atau tamu dengan berusaha memberikan kepuasan kepada tamu tersebut, walaupun kondisi mereka dalam keadaan keterbatasan. Warga betang memiliki hubungan kekeluargaan yang luas, serta keterbukaannya terhadap pendatang dari luar komunitas mereka. Bahkan warga betang dapat menjadi lebih luas lagi dengan perkawinan lintas etnis, agama dan budaya (Rusali, hasil wawancara).

Perlakuan terhadap orang lain di luar komunitas betang memang mendapat tanggapan yang positif dari warga masyarakat lainnya yang bukan Dayak. Mereka ikut merasakan bagaimana perlakuan komunitas betang yang pada prinsipnya menganggap bahwa orang lain adalah pahari. Hal itu menurut salah satu warga di luar komunitas betang Damang Batu bahwa dalam pergaulan sehari-hari dan dalam menyelesaikan masalah yang ada di desa penekanannya pada prinsip kebersamaan. Misalnya saja, dalam pertemuan atau obrolan sehari-hari pemakaian kata itah yang sering dilontarkan: "akan lewu itah kea" (untuk kampung kita juga), "uras itah ehjaton oloh beken hetoh" (tidak orang lain di sini). Ungkapan-ungkapan tadi kami artikan sebagai perhatian dan sikap komunitas betang terhadap orang lain, bahwa ketika sudah menjadi warga Desa 
LINGUA, Vol. 14, No. 1, Maret 2017

p ISSN: 1979 9411; e ISSN: 2442 238X

Http://lingua.pusatbahasa.or.id; Email: presslingua@gmail.com

Center of Language and Culture Studies, Surakarta, Indonesia

Suwarno. 2017. Budaya Huma Betang Masyarakat Dayak Kalimantan Tengah

dalam Globalisasi: Telaah Konstruksi Sosial. Lingua (2017), 14(1): 89 102.

Tumbang Anoi walaupun bukan keturunan Dayak, tetap dianggap sebagai saudara mereka.

Rasa kebersamaan itu sangat menonjol dalam keseharian para penghuni betang terlepas dari perbedaan-perbedaan dimiliki. Istilah hapahari yang menjadi pegangan penghuni betang dulu dan sekarang menjadi luas penerapannya tidak hanya pada interaksi sesama penghuni betang tetapi bagi orang lain di luar betang. Menurut salah seorang yang merehab betang Damang Batu, bahwa penghuni betang selalu menanamkan prinsip bahwa tamu adalah segala-galanya. Melayani tamu dulu baru melayani anggota keluarga. Kepuasan tamu adalah kebahagiaan bagi mereka. Dulu pernah ada tamu berkunjung dan mereka menyuguhkan kopi, namun gula hanya cukup untuk minuman kopi tamu. Mereka rela tidak minum kopi asal tamu minum kopi. Penghargaan dan penghormatan mereka kepada tamu menurut penghuni betang adalah salah satu kahanjak atei (kebahagiaan) bagi mereka. Menurut ibu Asie, bila tamu tidak puas dengan pelayanan mereka, maka hati mereka sakit dan sebaliknya.

\section{Handep}

Kearifan betang Damang Batu yang sangat kental sampai saat ini dan menjadi warisan budaya yang tidak pernah sirna adalah handep. Menurut salah satu penghuni betang Damang Batu, handep merupakan tolong-menolong, pandohop (bantuan), saling mandohop (membantu). Menurutnya, handep biasanya terlihat secara konkret pada upacara kematian (tiwah), upacara perkawinan, membuka lahan atau ingin menanam padi, serta upacara-upacara adat lainnya.

Semangat tolong-menolong yang tinggi dalam komunitas betang dinampakkan dalam handep. Handep dilakukan dalam segalahal segi kehidupan dimana pekerjaan tersebut tidak dapat dilakukan sendiri tapi membutuhkan pertolongan warga betang lainnya. Untuk melakukan handep diperlukan hati yang bersih dan penuh kasih, jauh dari kebencian dan kedengkian. Sehingga pekerjaan yang berat menjadi ringan ketika dikerjakan bersama dengan sukacita dan ketulusan. Ketika hal itu tidak diperhatikan oleh seseorang maka dianggap sebagai orang egois dan tidak hidup bersama orang lain.

Praktek handep dibawa secara turun-temurun. Tidak ada unsur paksaan bagi masyarakat yang akan melakukan budaya ini. Ketika ada kematian, secara solider datang membantu keluarga yang berduka, dengan membawa beras, gula, kopi dan uang seadanya. Hal ini dimaksudkan untuk meringankan beban keluarga yang sedang berduka. Menurut salah satu penghuni betang, handep yang paling kental dulu terlihat dalam persiapan dan pelaksanaan upacara tiwah dan pada masa sekarang tiwah sudah jarang dilakukan karena warga Kaharingan sudah makin sedikit dan banyak yang berpindah ke Agama Kristen. Namun semangat handep dalam tiwah masih bisa terasa dalam upcara kematian di Desa Tumbang Anoi.

Handep juga dilakukan dalam perkawinan. Handep yang diberikan sangat menolong bagi keluarga yang melaksanakan perkawinan, baik melalui benda, materi, tenaga, pikiran dan perhatian. Terlebih apabila yang melaksanakan acara perkawinan tersebut adalah orang yang tidak mampu secara ekonomi, dan memerlukan sokongan 
LINGUA, Vol. 14, No. 1, Maret 2017

p ISSN: 1979 9411; e ISSN: 2442 238X

Http://lingua.pusatbahasa.or.id; Email: presslingua@gmail.com

Center of Language and Culture Studies, Surakarta, Indonesia

Suwarno. 2017. Budaya Huma Betang Masyarakat Dayak Kalimantan Tengah

dalam Globalisasi: Telaah Konstruksi Sosial. Lingua (2017), 14(1): 89 102.

untuk meringankan beban yang dihadapinya. Perkawinan adalah salah satu yang sangat penting dalam kehidupan masyarakat Dayak Ngaju, karena apabila pelaksanaannya kacau dan tidak sesuai dengan yang diharapkan maka harga diri, martabat keluarga akan tercoreng. Karena keluarga tersebut juga berada dalam suatu komunitas masyarakat, maka martabat, kehormatan dari keluarga tersebut adalah martabat, kehormatan dari komunitas yang berada di sekitarnya. Oleh karena itu handep yang dilakukan oleh masyarakat setempat dalam rangka menjaga kehormatan dan martabat bersama.

Nilai handep juga terlihat dari kerja bakti di desa dan pada saat manugal (menanam padi) sampai manggetem (memanen padi). Ketika musim menanam padi tiba, warga masyarakat datang beramai-ramai membantu teman yang akan menanam padi. Menurut salah satu warga Desa Tumbang Anoi, manugal membutuhkan waktu kurang lebih 1-3 bulan untuk handep. Bahkan untuk mengerjakan ladang satu keluarga saja membutuhkan waktu 2-4 hari. Apabila yang biasanya melaksanakan handep tidak dapat hadir karena sakit atau keperluan mendesak lainnya, maka ada anggota keluarga lain menggantikan untuk meneruskan handep, sehingga kontinuitas handep dari sesama tetap terlaksana. Biasanya yang memiliki sawah atau lahan menyediakan makanan kepada yang membantu.

Menurut salah satu anggota jemaat GKE yang juga adalah warga komunitas betang Damang Batu praktek handep juga terlihat ketika acara kebaktian keluarga di Desa Tumbang Anoi. Sebelum acara kebaktian pada sore harinya, anggota jemaat dan penghuni betang ikut membantu persiapan kebaktian pada pagi harinya. Kedatangan Ibu-ibu untuk membantu tuan rumah yang akan melaksanakan kebaktian sangat spontan dan tanpa diundang. Handep dalam kebaktian keluarga ini sudah membudaya di Desa Tumbang Anoi, keluarga yang telah dihandep merasakan seperti memiliki hutang kepada anggota jemaat lain yang akan melaksanakan kebaktian apabila tidak melakukan handep kepada anggota jemaat yang telah membantunya. Menurut ibu Rensie, yang datang untuk melakukan handep kebaktian keluarga tidak hanya anggota jemaat GKE saja, tetapi penghuni betang juga ikut ambil bagian membantu bersama warga jemaat lainnya.

\section{Belom Bahadat}

Belom bahadat (hidup beradab dan memiliki etika) dipahamioleh komunitas betang sebagai aturan atau tata krama yang mengatur kehidupan bersama, yaitu menghargai adat yang berlaku dalam wilayah komunitas adat yang bersangkutan. Dalam rumah betang ini setiap kehidupan individu dalam rumah tangga dan masyarakat diatur melalui kesepakatan bersama yang dituangkan dalam hukum adat.

Menurut salah satu penghuni betang Damang Batu, penghuni betang terikat dengan yang namanya pali (pantangan). Pali samasekali tidak boleh dilanggar oleh penghuni betang. Misalnya, apabila pergi ke hutan, maka tidak boleh buang air kecil sembarangan, karena dipercayai hutan merupakan tempat para roh leluhur. Kasus yang lain, tidak boleh sembarangan menebang kayu-kayu besar, karena dipercayai kayu-kayu besar memiliki penunggu. 
LINGUA, Vol. 14, No. 1, Maret 2017

p ISSN: 1979 9411; e ISSN: 2442 238X

Http://lingua.pusatbahasa.or.id; Email: presslingua@gmail.com

Center of Language and Culture Studies, Surakarta, Indonesia

Suwarno. 2017. Budaya Huma Betang Masyarakat Dayak Kalimantan Tengah dalam Globalisasi: Telaah Konstruksi Sosial. Lingua (2017), 14(1): 89 102.

Kemudian, kasus lain yang menggambarkan belom bahadat adalah terlihat dari hubungan antara sesama manusia, menurut salah satu warga komunitas betang di Desa Tumbang Anoi dalam hubungan antar sesama harus menjaga perasaan orang lain, tidak boleh bertindak semena-mena terhadap orang lain. Salah satu juga belom bahadat tercermin dari warga yang menjaga kesucian kampung, misalnya warga dilarang untuk duduk berduaan dengan lawan jenis di tempat-tempat tersembunyi; warga juga tidak diperbolehkan menikah dengan yang masih memiliki ikatan darah; dalam rumah tangga, bila istri sedang mengandung sang suami tidak diperbolehkan membunuh binatang, bila pergi ke hutan tidak diperbolehkan mengeluarkan kata-kata kotor.

Menurut mantir adat di Desa Tumbang Anoi bahwa aturan-aturan adat dimaksudkan agar warga setempat dapat hidup rukun dan keseimbangan kehidupan manusia tetap terjaga. Misalnya saja dalam acara perkawinan, siapa saja yang akan melangsungkan perkawinan maka ada aturan-aturan adat yang harus dipenuhi oleh kedua mempelai. Seorang laki-laki harus menyerahkan sebidang tanah kepada mempelai perempuan sebagai syarat acara adat dapat dilangsungkan. Kemudian, pada tahap akhir pelaksanaan dilakukan prosesi Maruah Pali. Maruah artinya menghapus atau mengakhiri. Pali berarti tabu atau pantangan. Jadi acara Maruah Pali adalah acara yang dilaksanakan sebagai tanda berakhirnya masa berpantangan bagi kedua mempelai. Karena setelah acara perkawinan, kedua mempelai harus menjalani masa Pali yaitu masa berpantangan selama tiga hari atau paling lama tujuh hari sejak hari perkawinan mereka. Pantangan yang tidak boleh mereka lakukan selama menjalani masa Pali adalah: melakukan hubungan suami istri dan mengadakan perjalanan jauh. Setelah masa Pali habis, diadakan upacara Maruah Pali bagi kedua penganten yaitu ditandai dengan pemotongan satu ekor ayam yang kemudian kedua mempelai ditampungtawari (dibersihkan) oleh kedua orang tua. Selanjutnya keduanya diajak berkunjung ke keluarga wanita.

Apabila segenap aturan-aturan adat istiadat tadi dilanggar, menurut salah satu tokoh adat Desa Tumbang Anoi maka menurut kepercayaan warga siapa yang melanggar akan mendapatkan tulah (hukuman). Tulah tersebut dapat berupa sanksi adat, sanksi sosial dari masyarakat dan juga berdampak pada sakit penyakit dan bencana. Misalnya saja, pernah salah satu anak remaja Desa Tumbang Anoi yang tidak sengaja buang air kecil di ancak (makanan untuk para roh leluhur), maka dalam beberapa hari ke depan kemaluannya membesar (bengkak). Untuk menyembuhkan penyakit ini, maka dilakukan upacara permohonan maaf kepada roh-roh leluhur.

Menurut kepala Desa Tumbang Anoi belom bahadat merupakan identitas masyarakat betang yang bersifat cair dan terus menerus ditampilkan ke dalam kehidupan masyarakat sehingga memberikan makna penting bukan hanya bagi para penghuni betang tetapi juga dalam pergaulan komunitas betang yang sifatnya lebih luas. Belom bahadat ini menurutnya juga merupakan salah satu prinsip orang Dayak secara umum untuk menjaga keseimbangan alam semesta agar warga dapat hidup damai dan tentram. 
LINGUA, Vol. 14, No. 1, Maret 2017

p ISSN: 1979 9411; e ISSN: 2442 238X

Http://lingua.pusatbahasa.or.id; Email: presslingua@gmail.com

Center of Language and Culture Studies, Surakarta, Indonesia

Suwarno. 2017. Budaya Huma Betang Masyarakat Dayak Kalimantan Tengah

dalam Globalisasi: Telaah Konstruksi Sosial. Lingua (2017), 14(1): 89 102.

\section{Hapakat Kula}

Hapakat kula (saling bermufakat) merupakan ciri khas kehidupan para penghuni betang. Menurut penuturan penghuni betang menyelenggarakan musyawarah dalam setiap kegiatan yang menyangkut kepentingan bersama adalah tradisi penghuni betang sejak abad silam. Damang Batu merupakan kepala Suku Dayak Kadorih yang paling disegani oleh masyarakat Tumbang Anoi selalu memimpin musyawarah apabila kampung menghadapi masalah, baik itu berkaitan dengan serangan musuh maupun masalah adat. Damang batu juga terkenal sebagai pemrakarsa hapakat kula dalam perdamaian Tumbang Anoi, sehingga Tumbang Anoi menjadi tempat bersejarah bagi masyarakat Dayak.

Hapakat kula menurutnya memiliki kesamaan makna dengan hatamuei lingu nalata, yaitu saling kenal mengenal serta bertukar pikiran dan pengalaman. Dalam bermasyarakat, orang Dayak harus mengedepankan musyawarah dan mufakat. Putusan dari musyawarah dan mufakat tersebut, diambil sebagai kesepakatan bersama yang harus dijalankan dengan benar. Paling kental yang sering terjadi di Desa Tumbang Anoi dulunya adalah pertemuan akbar Tumbang Anoi yang digagas oleh Damang Batu. Dalam mempersiapkan rapat akbar tersebut, Damang Batu selalu mengedepankan prinsip hatamuei lingu nalata.

Menurut Kepala Desa Tumbang Anoi pada saat sekarang, prinsip hatamuei lingu nalata sering dilakukan pada rapat-rapat tentang kemajuan desa dan juga upaya-upaya menyelesaikan perselisihan antar warga dan hubungan rumah tangga. Dalam menyelesaikan sengketa atau perselisihan, warga Desa Tumbang Anoi sudah terbiasa melakukan musyawarah dan bertukar pikiran satu dengan lainnya. Memang cara ini memakan waktu dan namun keputusan yang dihasilkan akan lebih diterima oleh seluruh warga bila melalui musyawarah dan mufakat.

\section{KONSTRUKSI SOSIAL BUDAYA HUMA BETANG: ANTITESIS}

Bila bersandar pada kerangka dialektis Berger, menjadi jelas bahwa budaya huma betang terbentuk dari tiga momentumnya, yaitu eksternalisasi, internalisasi dan objektivasi. Huma betang merupakan realitas simbol yang diinternalisasi dan dieksternalisasi secara berulang-ulang hingga membentuk sebuah budaya huma betang. Realitas akhir yang terjadi melalui proses dialektika tadi adalah dengan munculnya beberapa nilai-nilai budaya yang dianggap sebagai definisi realitas masyarakat Dayak guna menuntun tingkah laku dan tindakan berpola dari mereka.

Dalam beberapa hasil penelitian dan kajian yang dilakukan penulis, Masyarakat Dayak dengan sangat menjujung budaya huma betang dan budaya ini sangat mengakar dalam kehidupan mereka. Makna yang terkandung dalam budaya huma betang ini menurut penulis paling kental adalah komunalisme, yang di dalamnya terkandung nilai kebersamaan, tolong menolong, egaliter, kekeluargaan, mufakat dan hidup beradat. Pola-pola tersebut mengakar terutama sekali pada masyarakat Dayak pedalaman. Namun bukan berarti masyarakat Dayak perkotaan terbebas dari ikatan tersebut, dalam beberapa kasus kehidupan masyarakat Dayak perkotaan masih meresapi budaya betang. 
LINGUA, Vol. 14, No. 1, Maret 2017

p ISSN: 1979 9411; e ISSN: 2442 238X

Http://lingua.pusatbahasa.or.id; Email: presslingua@gmail.com

Center of Language and Culture Studies, Surakarta, Indonesia

Suwarno. 2017. Budaya Huma Betang Masyarakat Dayak Kalimantan Tengah

dalam Globalisasi: Telaah Konstruksi Sosial. Lingua (2017), 14(1): 89 102.

Misalnya terlihat jelas dalam acara kematian, perkawinan dan juga dalam pergaulan sehari-hari yang selalu mengedepankan kebersamaan.

Komunalisme merupakan konstruksi sosial Masyarakat Dayak sendiri. Hampir semua sendi kehidupan masyarakat Dayak selalu berdasar pada konsep tersebut.Dalam kehidupan sosial, komunalisme merupakan tali pengikat interaksi sosial masyarakat Dayak. Dalam kehidupan politik dan pembangunan, budaya betang dianggap sebagai falsafah hidup, terbukti dengan diterbitkannya Peraturan Daerah Provinsi Kalimantan Tengah Nomor 16 Tahun 2008 Tentang Kelembagaan Adat Dayak Di Kalimantan Tengah (selanjutnya disingkat Perda No.16/2008) yang didalamnya terdapat istilah 'falsafah hidup "Budaya Huma betang atau Belom Bahadat".

Tesis atau pandangan bahwa budaya huma betang merupakan realitas objektif dari kehidupan masyarakat Dayak dan menjunjung tinggi nilai-nilai komunalisme merupakan hal yang tidak terbantahkan sampai saat ini. Tidak dapat disangkal bahwa tesis ini pula yang sudah membentuk sejarah integrasi sosial masyarakat Dayak. Masyarakat Dayak bisa hidup berdampingan dengan siapa saja dan kepercayaan apa saja, ini adalah fakta yang bisa dibanggakan. Namun juga bila ditinjau dari perspektif lain, tesis ini sekaligus sebagai sebuah potensi disintegrasi di masa yang akan datang.

Gejala-gejala itu sudah mulai dirasakan saat ini, mulai dari gesekan tentang kepentingan identitas lokal dan nasionalisme, kompetisi global dan cita rasa lokal, mayoritas dan minoritas, demokrasi, dan masih banyak lagi gejala-gejala yang bermunculan. Kemampuan masyarakat Dayak untuk tetap resisten dengan nilai komunalisme tersebut justru semakin menyurutkan spirit mereka untuk bersaing di era sekarang ini. Nilai-nilai komunalisme itu dalam arti menghambat Masyarakat Dayak untuk lebih maju dan menonjol dari yang lain. Pun bila ada pemikiran untuk maju hal itu masih sebatas sebuah discourse namun tetap saja kemampuan untuk melakukan action terbelenggu oleh nilai lama. Padahal, bila diamati SDM untuk melakukan perubahan dan kreasi inovasi sangat potensial tersedia namun nilai budaya masyarakat Dayak yang dianggap sakral itu enggan untuk didobrak bahkan dilanggar. Dampak dari pelanggaran nilai-nilai komunalisme itu dirasakan sebagai beban struktural masyarakat Dayak dalam berinteraksi.

Potensi tersebut cukup beralasan apabila memandang konteks sekarang dan ke depan sebagai ruang dan waktu yang sudah diberi label sebagai era "globalisasi". Prinsip dan nilai komunalisme yang menjadi makna dari budaya huma betang itu, merupakan hasil atau produk masa lampau yang tidak sepaham lagi dengan era sekarang ini.

Sudah diketahui bersama bahwa era globalisasi sarat dengan persaingan, ruang dan waktu yang semakin sempit, ruang komunikasi dan informasi yang terbuka lebar, teknologi tinggi, spesialisasi dan pembagian kerja yang semakin sempit, dan lain-lain. Di sisi lain, konstruksi budaya huma betang masih mempertahankan nilai-nilai yang kontraproduktif dengan era berjalan dan masa yang akan datang. Dengan meninjau hal ini sangat relevan apabila tesis tentang budaya huma betang yang sarat akan nilai 
LINGUA, Vol. 14, No. 1, Maret 2017

p ISSN: 1979 9411; e ISSN: 2442 238X

Http://lingua.pusatbahasa.or.id; Email: presslingua@gmail.com

Center of Language and Culture Studies, Surakarta, Indonesia

Suwarno. 2017. Budaya Huma Betang Masyarakat Dayak Kalimantan Tengah

dalam Globalisasi: Telaah Konstruksi Sosial. Lingua (2017), 14(1): 89 102.

komunalisme dikonstruksi ulang dengan pandangan baru, dalam arti antitesis yang memuat nilai-nilai perjuangan dan kompetisi.

Apabila ditelisik lebih jauh, dengan mengamati huma betang yang ada kita akan melihat makna perjuangan, keberanian dan kepercayaan diri Masyarakat Dayak pada masa lampau sebagai argumen kita untuk mengatakan bahwa masyarakat Dayak sangat kompetitif dan memiliki inovasi. Hal ini dibuktikan ada tempat penyimpanan peralatan perang atau senjata untuk melawan musuh dan patung-patung di depan maupun di belakang huma betang bisa dimaknai sebagai kreatifitas dan inovasi masyarakat Dayak yang tidak kalah dengan masyarakat lainnya.

Budaya huma betang yang sarat akan nilai-nilai struggle dan inovasi semacam itulah yang perlu untuk dikonstruksikan pada masa kini dan yang akan datang. Dengan kemapanan tiga momentum tadi dalam proses konstruksi penulis yakin bahwa spirit untuk perjuangan, kepercayaan diri dalam berinovasi serta ranah kompetisi tidak akan menjadi kendala.

\section{PENUTUP}

Menjadi sebuah kontradiksi apabila nilai-nilai yang lama diubahsesuaikan dengan nilai-nilai yang baru. Serta merupakan sebuah penghinaan dan kecaman dari mereka yang selama ini dipersatukan dan terintegrasi dengan nilai-nilai tersebut. Budaya huma betang sendiri telah menjadi pahlawan dalam memperjuangkan integrasi masyarakat Dayak dalam perjalanan waktu. Namun sebuah keniscayaan apabila nilainilai tersebut tidak lagi dapat membawa perubahan ke arah yang lebih konstruktif. Persoalan globalisasi itu memang tidak bisa dihindari lagi dan mau tidak mau mesti dihadapi dengan segenap kemampuan yang ada. Tantangan untuk konstruksi ulang budaya betang tersebut sangatlah penting dilakukan mengingat pada masa sekarang globalisasi sudah dicanangkan oleh seluruh negara di dunia. Tentunya konstruksi ulang budaya huma betang itu harus dilakukan walaupun membawa implikasi serius bagi masyarakat. Perubahan merupakan salah satu implikasi besar yang segera akan terjadi. Namun perubahan pula sekaligus menjadi indikasi bagi kemajuan dan perkembangan masyarakat.

Beberapa pertimbangan yang bisa dilakukan dalam menggambarkan masalah di atas, yaitu sejak dini sudah dilakukan eksplorasi dan elaborasi budaya betang yang mengandung nilai budaya yang resisten dan survive dalam menangani kebutuhankebutuhan globalisasi. Melakukan konstruksi nilai budaya huma betang yang baru bukanlah pekerjaan yang mudah. Akan tetapi pada prinsipnya, agar hal ini dapat terbangun maka perubahan mindset adalah hal yang pertama yang mesti dilakukan. Secara tidak sengaja dengan adanya perubahan mindset ini pula proses internalisasi, eksternaslisasi dan objektivasi akan terjadi lagi dengan nilai-nilai baru dan pengalamanpengalaman baru. 
LINGUA, Vol. 14, No. 1, Maret 2017

p ISSN: 1979 9411; e ISSN: 2442 238X

Http://lingua.pusatbahasa.or.id; Email: presslingua@gmail.com

Center of Language and Culture Studies, Surakarta, Indonesia

Suwarno. 2017. Budaya Huma Betang Masyarakat Dayak Kalimantan Tengah

dalam Globalisasi: Telaah Konstruksi Sosial. Lingua (2017), 14(1): 89 102.

\section{DAFTAR PUSTAKA}

Berger, Peter L., 1994. Langit Suci: Agama Sebagai Realitas Sosial, Jakarta: LP3ES.

Berger, Peter L., dan Thomas Luckmann,1990. Tafsir Sosial atas Kenyataan, Jakarta : LP3ES.

Jacobus E. Frans L. Concordius Kanyan, 1994.Rumah betang Sebagai Pusat Kebudayaan Dayak, Jakarta: PT Grasindo bekerja sama dengan LP3S - Institut of Dayakology Research and Development.

Maunati, Yekti. 2004. IDENTITAS DAYAK (Komodifikasi dan Politik Kebuayaan. Lkis.Yogyakarta.

P.M. Laksono, dkk., (eds.), 2006. Pergulatan Identitas Dayak dan Indonesia: Belajar dari Tjilik Riwut, Yogyakarta: Galangpress.

Roedy Haryo Widjono, 1998. Masyarakat Dayak Menatap Hari Esok, Jakarta: Grasindo bekerja sama dengan Lembaga Bina Benua Puti Janji-LPPS-KWI.

Sukin, 2012. Fungsi Bangunan Rumah Panjang (betang) Bagi Masyarakat Desa Saham Kecamatan Sengah Temila Kabupaten Landak Provinsi Kalimantan Barat, Skripsi (tidak diterbitkan), Program Studi Pendidikan Sejarah, FKIP, Salatiga: UKSW.

Sutrisno Mudji dan Hendar Putranto. 2005. Teori-Teori Kebudayaan. Kanisius. Yogyakarta.

Yosia Nugrahaningsih, 2013. Proses Komunikasi Masyarakat Dayak Ngaju Dalam Rangka Melestarikan Nilai-Nilai Hidup Huma Betang, Studi di Lingkungan Masyarakat Dayak Ngaju di Desa Buntoi. Tesis (tidak diterbitkan). Program Studi Ilmu Komunikasi, Program Pascasarjana, Universitas Sebelas Maret. 